\title{
Customer satisfaction and loyalty drivers in the Zambian mobile telecommunications industry
}

\author{
Mlenga G. Jere \\ Graduate School of Business \\ University of Cape Town, South Africa
}

Alick Mukupa

University of Lusaka, Zambia

\section{Key words}

customer satisfaction, customer loyalty, mobile telecommunications, Zambia

\begin{abstract}
This paper explores the extent to which customer satisfaction, service quality, customer service, price, corporate image, and network coverage influence customer loyalty in the mobile telecommunications industry in the emerging market country of Zambia. The study is important because emerging market countries including Zambia present a contextual setting in which there has been very high growth in mobile phone penetration within a short period of time. Based on survey data from a convenience sample of 221 mobile subscribers, and using partial least squares analysis, the study found that the antecedents of customer satisfaction (i.e., service quality, customer service, corporate image, price, and network coverage) explained $54 \%$ of the variance in customer satisfaction while customer satisfaction itself explained $37.4 \%$ of the variance in customer loyalty. Though service quality, customer service, corporate image, and network coverage were positively related to customer satisfaction as expected, there was no evidence to support the hypothesized negative relationship between the price level and customer satisfaction.
\end{abstract}

Corresponding author: Mlenga G. Jere

Email addresses for corresponding author: mlenga.jere@gsb.uct.ac.za

First submission received: $17^{\text {th }}$ February 2018

Revised submission received: $24^{\text {th }}$ April 2018

Accepted: 22 $2^{\text {nd }}$ May 2018

\section{Introduction}

In today's competitive markets, customer loyalty is a major concern for firms. To create loyal customers, firms have to understand the factors that drive customer loyalty, an important and frequently addressed subject in marketing (Heskett and Sasser, 2010). The value of customer loyalty stems from the notion that loyal customers contribute to the value of firms by enabling firms to minimize customer acquisition costs by focusing on customer retention (Boora and Singh, 2011). Research suggests that customer loyalty is a key determinant of long-term brand viability (Krishnamurthi and Raj, 1991). Developing and increasing customer loyalty is therefore crucial for a firm's growth and performance (Lee and Cunningham, 2001). It is contended that a defensive strategy focused on existing customer retention is more important than an aggressive strategy focused on new customer acquisition (Fornell, 1992; Ahmad and Buttle, 2002). An important driver of customer loyalty is customer satisfaction. Customers make their assessment of customer satisfaction based on a number of value drivers or individual product features relevant to the purchase. In the literature, value drivers that have been used as determinants of customer satisfaction in mobile telecommunications research include service quality, price, corporate image, customer service, and network coverage. These factors were used to measure customer satisfaction in this study.

Emerging market countries including those in Africa have experienced very rapid growth in the use of mobile technology. To illustrate, between 2002 and 2014, cell phone ownership amongst adults grew from $8 \%$ to $83 \%$ and $33 \%$ to $89 \%$ in Ghana and South Africa respectively compared with growth from $64 \%$ to $89 \%$ in the US (see for example, Pew Research Center, 2015). According to the Zambia Information and Communications Authority (ZICTA, 2013), the penetration rate in Zambia experienced a 
growth rate of about $75 \%$ from 1.9 per 100 inhabitants in 2003 to 77 per 100 inhabitants by 2013. ZICTA also estimates that by December 2014, there were 10.1 million subscribers distributed amongst the three mobile service providers in Zambia namely MTN (48\%), Airtel (37\%), and Zamtel (15\%) (The Post, 2015). It is in the context of this rapid transition in mobile penetration that this study investigated the drivers of customer satisfaction and customer loyalty in the Zambian mobile telecommunications industry. The specific research objectives of the study were to: a) assess the effect of corporate image on customer satisfaction, b) assess the effect of price on customer satisfaction, c) assess the effect of network coverage on customer satisfaction, d) assess the effect of service quality on customer satisfaction, e) assess the effect of customer service on customer satisfaction, and f) assess the effect customer satisfaction on customer loyalty.

\section{Literature review}

\subsection{Customer loyalty and customer satisfaction}

Oliver (1999, p.34) describes loyalty as "a deeply held commitment to rebuy or repatronize a preferred product/service consistently in the future, thereby causing repetitive same-brand purchasing, despite situational influences and marketing efforts having the potential to cause switching behavior." It is in part a reflection of how confident customers are about the future of the offering and the supplier's future that takes into account the competitive landscape. Customer loyalty is important because it is closely associated with business survival and growth (Kim, Park, and Jeong, 2004). Given the importance of customer loyalty, it is imperative to understand its determinants (Kumar, Batista and Maull, 2011). Previous research demonstrates that increasing customer satisfaction contributes to customer retention and customer loyalty (Kim et al., 2004, Gerpott, Rams and Schindler, 2001). Customer satisfaction is defined by Gerpott et al. (2001, p.253-254) as "an experience-based assessment made by the customer of how far his own expectations about the individual characteristics or the overall functionality of the services obtained from the provider have been fulfilled." It is a consumer's post-purchase evaluation and affective response to an offering (Oliver, 1992) and an important predictor of repurchase intentions, wordof-mouth recommendations, and customer loyalty (Eggert and Ulaga, 2002). High customer satisfaction contributes to increased customer loyalty (Fornell, 1992) while low customer satisfaction implies greater customer turnover and higher customer replacement costs (Anderson, Fornell and Leymann, 1994). Though a positive correlation exists between customer satisfaction and customer loyalty (Dick and Basu, 1994), customer loyalty may be observed without high customer satisfaction being in place (Gerpott et al. 2001).

In mobile telecommunication services research, customer satisfaction is as a strong driver of customer loyalty. For example, Lim, Widdows and Park's (2006) study of the US mobile services market found customer satisfaction to be a strong predictor of customer loyalty. In the Taiwanese mobile services market, Liu et al. (2011) found that satisfied customers were more likely to stay with their carrier and also recommend them to others. An investigation of customer loyalty determinants in the Nigerian telecommunications sector found that service quality, customer satisfaction, and corporate image were important drivers of customer loyalty (Adeleke and Aminu, 2012). However, while positive relationships between customer satisfaction and customer loyalty are widely reported; some studies have discovered a negative relationship between the two variables. For example, Coyles and Gokey (2005) observed that customer satisfaction on its own is not a strong indicator of customer loyalty even though it plays an important role in combination with other factors such price, customer service, and service quality. Boohene and Agyapong's (2011) analysis of customer loyalty in the Ghanaian telecommunications sector discovered that customer satisfaction had a significant, but negative effect on loyalty, implying that despite the low levels of satisfaction, consumers still remained loyal to their network providers. However, the general consensus is that customer satisfaction has a strong positive effect on customer loyalty. Therefore, it is hypothesized that:

Hypothesis 1: Higher levels of customer satisfaction are positively associated with higher levels of customer loyalty in the Zambian mobile telecommunications industry. 


\subsection{Determinants of customer satisfaction}

While many factors influence customer satisfaction, it is difficult to find one study that has investigated all the influencing factors simultaneously and jointly (Aydin and Ozer, 2005). Based on the literature, the following determinants of customer satisfaction are important and included in this study: service quality, price, customer service, corporate image, network coverage, and customer satisfaction.

Service quality: Quality is customer's overall impression of the relative inferiority or superiority of an organization and its service offerings (Bitner et al., 1990). Research shows that service quality positively influences customer satisfaction (Gotlieb, Grewal, and Brown, 1994) and that it is a major determinant of customer retention (Venetis and Ghauri, 2004) as it results in repeat sales, increased market share, customer loyalty (Buzzell and Gale, 1987), and premium prices (Brown, Churchill, and Peter, 1993). In the telecommunications industry, service quality is also known to drive customer satisfaction (Deng, et al., 2010). The foregoing discussion leads to the following hypothesis:

Hypothesis 2: Higher levels of service quality are positively associated with higher levels of customer satisfaction in the Zambian mobile telecommunications industry.

Price: To acknowledge that offering high levels of service quality may be not sufficient to attract and retain customers; marketers increasingly rely on both price and service quality in their competitive strategies (Haquea et al., 2010). While Bolton and Drew (1991) found that price considerations influenced customer loyalty; Kim, Park, and Jeong (2016) found that price does not have a significant effect on customer satisfaction with smartphones. Adeleke and Aminu's (2012) study in the Nigerian telecommunications sector concluded that price was not a determinant of customer satisfaction and customer loyalty. However, Martín-Consuegra et al. (2007) argued that perceived price fairness influences customer satisfaction and leads to customer loyalty. From the foregoing, it can be hypothesized that:

Hypothesis 3: Fair pricing is positively associated with higher levels of customer satisfaction in the Zambian mobile telecommunications industry.

Customer service: Customer service is known to be an important driver of customer loyalty and profitability (Prentice, 2014). The provision of excellent customer service can help with customer retention (Lucas, 2005) and customer loyalty (Ganguli and Roy, 2011). Customer service also offers a basis for service provider differentiation (McDougall and Levesque, 2000). From the foregoing discussion, it is evident that mobile service providers should also offer good customer service, hence the following hypothesis:

Hypothesis 4: Higher levels of customer service are positively associated with higher levels of customer satisfaction in the Zambian mobile telecommunications industry.

Corporate image: Corporate image is an important factor in the overall judgment of service providers (Lai, Griffin and Babin, 2009) that is associated with customer loyalty (e.g. Bloemer, de Ruyter and Peeters, 1998). It is the customer's perception of the firm that represents its reputation and prestige (Kim and Lee, 2011). A positive corporate image contributes to the generation of customer satisfaction (Aydin and Ozer, 2005) and customer loyalty (Anderson et al., 1994). For example, in the Chinese telecommunications industry, corporate image was found to significantly impact on services quality, customer value, customer satisfaction, and customer loyalty (Liu, 2008). It is therefore hypothesized that:

Hypothesis 5: A positive corporate image is positively associated with higher levels of customer satisfaction in the Zambian mobile telecommunications industry.

Network coverage: Network coverage is an important aspect of customer service as it relates to ensuring mobile service availability as customers expect. It is an important element that customers use to assess mobile service quality. Wider network coverage was found to increase perceived quality in Ethiopia (Negi, 2009) and customer satisfaction in Nigeria (Ibok, 2008) and Hong Kong (Woo and Fock, 1999). Thus, network coverage affects service quality and consequently customer satisfaction, hence the hypothesis:

Hypothesis 6: Higher network coverage is positively associated with higher levels of customer satisfaction in the Zambian mobile telecommunications industry. 


\section{Method}

This study adopted a survey design carried out in Lusaka, Zambia using a convenience sample of mobile subscribers over a three-week period; from November 11 to December 13, 2015. A total of 300 questionnaires were administered; of which 221 were correctly completed and returned. The questionnaire sought information on seven constructs, namely customer loyalty, customer satisfaction, corporate image, service quality, price, customer service, and network coverage. The first part of the instrument dealt with demographic variables while the second part of the questionnaire sought information on the seven constructs using 5-point Likert-type items. Respondents were asked to indicate their levels of agreement from 1 (strongly agree) to 5 (strongly disagree). Table 1 shows the measurement items and their source. Partial least squares (PLS) analysis was used to analyze the data using SmartPLS2 (Ringle, Wende and Will, 2005).

\begin{tabular}{|c|c|c|}
\hline Latent variable & Indicator variable & Sources \\
\hline \multirow[t]{4}{*}{$\begin{array}{l}\text { Customer } \\
\text { loyalty }(\mathrm{CL})\end{array}$} & $\begin{array}{l}\text { I am loyal to my service provider and consider it as my first choice } \\
\text { amongst the other mobile operators (CL1). }\end{array}$ & $\begin{array}{l}\text { Adeleke and Suraju } \\
(2012)\end{array}$ \\
\hline & $\begin{array}{l}\text { I intend to stay with my service provider for a very long time } \\
\text { (CL2). }\end{array}$ & $\begin{array}{l}\text { Liu et al. (2011), Gerpott } \\
\text { et al. (2001) }\end{array}$ \\
\hline & $\begin{array}{l}\text { My loyalty to my service provider is a result of the satisfaction I } \\
\text { get from it (CL3). }\end{array}$ & Authors \\
\hline & I will recommend my mobile network provider to friends (CL4). & $\begin{array}{l}\text { Liu et al. (2011), Gerpott } \\
\text { et al. (2001) }\end{array}$ \\
\hline \multirow{2}{*}{$\begin{array}{l}\text { Customer } \\
\text { satisfaction (CS) }\end{array}$} & Overall, I am satisfied with my mobile service provider (CS1). & Gerpott et al. (2001) \\
\hline & $\begin{array}{l}\text { The services rendered by my service provider are close to what I } \\
\text { expect (CS2). } \\
\text { My service provider is a good company to do business with (CS3). }\end{array}$ & $\begin{array}{l}\text { Adeleke and Suraju } \\
(2012) \\
\text { Rajaobelina and } \\
\text { Bergeron (2009) }\end{array}$ \\
\hline \multirow[t]{4}{*}{$\begin{array}{l}\text { Service quality } \\
\text { (SQ) }\end{array}$} & My mobile network is wide and extensive (SQ1). & $\begin{array}{l}\text { Adeleke and Suraju } \\
(2012)\end{array}$ \\
\hline & Calls are always clear on my network every time I use it (SQ2). & $\begin{array}{l}\text { Adeleke and Suraju } \\
\text { (2012), Gerpott et al. } \\
(2001)\end{array}$ \\
\hline & $\begin{array}{l}\text { I maintain my network because of the low rate of call failure } \\
\text { (SQ3). }\end{array}$ & Authors \\
\hline & $\begin{array}{l}\text { I am satisfied with the level of service quality offered by my } \\
\text { service provider (SQ4). }\end{array}$ & Authors \\
\hline Price (PR) & $\begin{array}{l}\text { The price I pay is commensurate with the quality of service I } \\
\text { receive on my network (PR1). } \\
\text { I will stick with my network when I feel that the price being } \\
\text { charged is relatively fair (PR2). }\end{array}$ & $\begin{array}{l}\text { Adeleke and Suraju } \\
\text { (2012) } \\
\text { Author }\end{array}$ \\
\hline \multirow[t]{4}{*}{$\begin{array}{l}\text { Customer } \\
\text { service (CSE) }\end{array}$} & $\begin{array}{l}\text { If I am not happy because my mobile service provider charges } \\
\text { higher prices, I will switch to a competitor (PR3). } \\
\text { My service provider's members of staff are courteous and friendly } \\
\text { in handling my grievances and complaints CSE1). }\end{array}$ & $\begin{array}{l}\text { Adeleke and Suraju } \\
(2012) \\
\text { Adeleke and Suraju } \\
(2012)\end{array}$ \\
\hline & $\begin{array}{l}\text { I consider prompt and quality customer service as one of the most } \\
\text { important considerations in the evaluation of a network (CSE2). }\end{array}$ & $\begin{array}{l}\text { Adeleke and Suraju } \\
(2012)\end{array}$ \\
\hline & $\begin{array}{l}\text { I am not happy with the long delay I experience each time I make } \\
\text { a call to my network's customer care line (CSE3). }\end{array}$ & $\begin{array}{l}\text { Adeleke and Suraju } \\
(2012)\end{array}$ \\
\hline & $\begin{array}{l}\text { My network's reputation for good service is not cheering and has } \\
\text { been a source of concern to me (CSE4). }\end{array}$ & $\begin{array}{l}\text { Adeleke and Suraju } \\
(2012)\end{array}$ \\
\hline \multirow[t]{3}{*}{$\begin{array}{l}\text { Corporate image } \\
(\mathrm{CI})\end{array}$} & $\begin{array}{l}\text { My network's name, variety of products, and quality of service } \\
\text { project it favourably in my mind (CI1). }\end{array}$ & $\begin{array}{l}\text { Adeleke and Suraju } \\
(2012)\end{array}$ \\
\hline & $\begin{array}{l}\text { Promptness in response to my call and in grievance handling by } \\
\text { customer care employees projects the service provider positively } \\
\text { in my mind (CI2). }\end{array}$ & $\begin{array}{l}\text { Adeleke and Suraju } \\
(2012)\end{array}$ \\
\hline & My network offers a range of promotions such as direct marketing & Adeleke and Suraju \\
\hline
\end{tabular}




\begin{tabular}{|l|l|l|}
\hline & and roadshows (CI3). & $(2012)$ \\
\hline & $\begin{array}{l}\text { I am loyal to my service provider because of the good corporate } \\
\text { image they portray (CI4). }\end{array}$ & Authors \\
\hline $\begin{array}{l}\text { Network } \\
\text { coverage (NC) }\end{array}$ & $\begin{array}{l}\text { I am satisfied with the network coverage offered by my service } \\
\text { provider and thus will not consider switching to another provider } \\
\text { (NC1). }\end{array}$ & Authors \\
\hline & $\begin{array}{l}\text { My network covers most of the places I frequent (NC2). } \\
\text { technology advancements by upgrading its network system } \\
\text { (NC3). } \\
\text { Most of the countries I visit are covered by my network though } \\
\text { roaming (NC4). }\end{array}$ & Authors \\
\hline
\end{tabular}

Table 1 Measurement items and their source

\section{Findings}

\subsection{Profile of respondents}

The sample consisted of more men $(128 ; 57.92 \%)$ than women $(93 ; 42.08 \%)$. Respondents with undergraduate and postgraduate degrees accounted for $15.84 \%$ and $18.55 \%$ respectively. All the mobile service providers were represented amongst the respondents as follows: 47.06\% Airtel subscribers, $34.39 \%$ MTN subscribers, and 18.55\% Zamtel subscribers.

\subsection{Measurement model}

There were initially 26 items employed in the model. However, 11 items were dropped from further analysis because their outer model loadings were lower than the .4 required for reflective indicators to be considered reliable (Hulland, 1999). The dropped items were SQ1, SQ2, CSE3, CSE4, PR1, CI2, NC1, NC4, CS1, CS2, CS4, and CL4. The PLS structural equation model algorithm converged after only two iterations; an indication that the estimation was good. The model assessment produced the results summarised in Table 2. The indicator loadings were all above the .4 threshold required for indicator reliabilty (Hulland, 1999). The majority (i.e., 60\%) of these loadings were above .7; which according to Sarstedt et al. (2014) means that the latent constructs explain more than $50 \%$ of the indicator's variance. T-values for significance testing were generated using the standard bootstrapping procedure of SmartPLS2 (drawing 221 cases, 5000 samples, and using the no sign change option). The T-statistics of the outer loadings were all greater than 1.96 and therefore also statistically significant except for the two indicators relating to PR.

\begin{tabular}{|c|c|c|c|c|c|}
\hline Latent variable & Indicators & Loadings & $\begin{array}{l}\text { Indicator } \\
\text { reliability } \\
\text { (loadings squared) }\end{array}$ & $\begin{array}{l}\text { Composite } \\
\text { reliability }\end{array}$ & AVE \\
\hline Customer satisfaction (CS) & CS2 & 1.000 & 1.000 & 1.000 & 1.000 \\
\hline \multirow[t]{3}{*}{ Customer loyalty (CL) } & CL1 & .818 & .669 & .883 & .716 \\
\hline & CL2 & .858 & .736 & & \\
\hline & CL3 & .861 & .741 & & \\
\hline \multirow[t]{2}{*}{ Service quality (SQ) } & SQ3 & .745 & .555 & .666 & .500 \\
\hline & SQ4 & .668 & .446 & & \\
\hline \multirow[t]{2}{*}{ Price (PR) } & PR2 & -.644 & -.415 & .052 & .577 \\
\hline & PR3 & .860 & .740 & & \\
\hline \multirow[t]{2}{*}{ Customer service (CSE) } & CSE1 & .905 & .820 & .083 & .614 \\
\hline & CSE2 & -.640 & -.410 & & \\
\hline \multirow{3}{*}{ Corporate image $(\mathrm{CI})$} & CI1 & .614 & .377 & .708 & .448 \\
\hline & $\mathrm{CI} 3$ & .703 & .494 & & \\
\hline & CI4 & .687 & .472 & & \\
\hline \multirow[t]{2}{*}{ Network coverage (NC) } & NC2 & .929 & .863 & .176 & .552 \\
\hline & NC3 & -.491 & -.241 & & \\
\hline
\end{tabular}

Table 2: Final PLS results summary 
The internal consistency reliability, convergent validity, and discriminant validity of the model were assessed as demonstrated in Table 2. Composite reliability was used to estimate the internal consistency reliability as suggested by Bagozzi and Yi (1988). The results show that it was above the .6 to .7 threshold (Bagozzi and Yi, 1988) and demonstrates high levels of internal consistency reliability for SQ, $\mathrm{CI}, \mathrm{CS}$, and CL, but not for CSE, PR, and NC. Convergent validity was assessed by examining each latent variable's Average Variance Extracted (AVE) for compliance with the minimum .5 which indicates that the latent variable explains $50 \%$ or more of the variance of its indicators (Bagozzi and Yi, 1988). All latent variables except CI met this requirement. Finally, the Fornell and Larcker (1981) criterion was used to assess discriminant validity. The criterion posits that discriminant validity is demonstrated if the square root of the AVE in each of the latent variables is larger than the correlation values in each column (see Table 3, square root of AVE values in bold). This criterion is met and demonstrates that the latent variables used in the path model are empirically distinct from each other (Table 3).

\begin{tabular}{|l|l|l|l|l|l|l|l|}
\hline & 1 & 2 & 3 & 4 & 5 & 6 & 7 \\
\hline Network coverage (NC) & .743 & & & & & & \\
\hline Customer satisfaction (CS) & .504 & 1.000 & & & & & \\
\hline Customer service (CSE & .254 & .547 & .784 & & & & \\
\hline Corporate image (CI & .289 & .508 & .458 & .669 & & & \\
\hline Customer loyalty (CL) & .397 & .612 & .473 & .581 & .846 & & \\
\hline Price (PR) & .121 & -.295 & -.277 & -.334 & -.239 & .760 & \\
\hline Service quality (SQ) & .125 & .374 & .357 & .382 & .431 & -.081 & .707 \\
\hline
\end{tabular}

Table 3: Fornell -Larcker criterion analysis for checking discriminant validity

\subsection{Structural model}

The structural model was examined for collinearity which leads to biased results when present (Hair, et al. 2011). The collinearity between all the exogenous variables and the endogenous variable were examined using Variance Inflation Factor (VIF) and Tolerance in the linear regression module of IBM SPSS 23. The collinearity statistics ( 5 or lower for VIF and .2 or higher for Tolerance) showed that collinearity was not evident and therefore did not negatively impact the results of the analysis. Using CS as the endogenous variable, the VIF and Tolerance values ranged from 1.202 to 1.566 and .639 to .832 respectively. For CL as the endogenous variable, the VIF and Tolerance values ranged from 1.298 to 2.176 and .460 to .770 respectively.

The path coefficients showing the predictive power of the exogenous variables are presented in Table 4. These show that NC $(\beta=.402)$ had the largest effect in predicting CS, followed by CSE $(\beta=.266)$, SQ $(\beta=.159)$ and CI $(\beta=.140)$. CS itself had a large effect on CL $(\beta=.612)$. Using Cohen's (1988) guidelines which categorise effect sizes as small $(\mathrm{r}=.1)$, medium $(\mathrm{r}=.3)$, or large $(\mathrm{r}=.5)$, the predictive power of CS on CL $(\beta=.612)$ is large while the that of NC on CS $(\beta=.402)$ is medium. All other effects on CS are small as they are under .3. To sum up, these findings suggest all hypotheses except hypothesis 4 are supported by the evidence as highlighted in Table 4. The five exogenous variables (SQ, CSE, PR, CI, and NC) moderately explain $54 \%$ of the variance in CS $\left(\mathrm{R}^{2}=.540\right)$ while CS itself explains $37.4 \%$ of the variance in $\mathrm{CL}\left(\mathrm{R}^{2}=.374\right)$. To examine the statistical significance and relevance of the relationships in the structural model, the bootstrapping procedure in SmartPLS2 was applied to generate T-statistics. The results in Table 4 show that all the exogenous variables except PR were statistically significant predictors of the applicable endogenous variables. 


\begin{tabular}{|l|l|l|l|l|}
\hline Path & Path coefficient & T-statistic & Hypothesis testing \\
\hline $\begin{array}{l}\text { Customer satisfaction (CS) - Customer loyalty } \\
\text { (CL) }\end{array}$ & .612 & $10.965^{* *}$ & .374 & H1: Supported \\
\hline $\begin{array}{l}\text { Service quality (SQ) - Customer satisfaction } \\
\text { (CS) }\end{array}$ & .159 & $2.879^{* *}$ & .540 & H2: Supported \\
\hline Price (PR) - Customer satisfaction (CS) & -.210 & 1.739 & & H3: Not supported \\
\hline $\begin{array}{l}\text { Customer service (CSE) - Customer } \\
\text { satisfaction (CS) }\end{array}$ & .266 & $4.828^{* *}$ & & H4: Supported \\
\hline $\begin{array}{l}\text { Corporate image (CI) - Customer satisfaction } \\
\text { (CS) }\end{array}$ & .140 & $2.345^{*}$ & & H5: Supported \\
\hline $\begin{array}{l}\text { Network coverage (NC) - Customer } \\
\text { satisfaction (CS) }\end{array}$ & .402 & $6.257^{\text {** }}$ & & H6: Supported \\
\hline
\end{tabular}

* significant at $p<.05,{ }^{* *}$ significant at $p<.01$

Table 4: T-statistics of path coefficients (inner models)

\section{Discussion and conclusions}

This study found that customer satisfaction has a significant and large positive effect on customer loyalty. This finding is supportive of previous studies (e.g., Liu et al., 2011). Evidently, providing subscribers with an experience which results in higher levels of satisfaction and loyalty is likely to be a profitable endeavor for service providers. Therefore, firms seeking high levels of customer loyalty in the Zambian mobile telecommunications industry need to invest in generating customer satisfaction by addressing the appropriate drivers of customer satisfaction. Amongst the five antecedents of customer satisfaction used in this study (i.e., SQ, CSE, PR, CI, and NC), network coverage was found to be the strongest determinant, confirming that higher levels of network coverage is indeed positively associated with higher levels of customer satisfaction are in the Zambian mobile telecommunications industry. This finding is consistent with other studies (e.g., Ibok, 2008). This implies that mobile service providers in Zambia should invest more in their network coverage if they are to have satisfied and loyal customers. The second strongest determinant of customer satisfaction was customer service, a confirmation that higher levels of higher levels of customer service are positively associated with higher customer satisfaction; consistent with the evidence reported literature (e.g., McDougall and Levesque, 2000). Therefore, in addition to improving network coverage, firms should ensure that their customer service is excellent if customer satisfaction and ultimately customer loyalty are to be achieved. Service quality was third in terms of its importance as a predictor of customer satisfaction as it was found to be positively associated with customer satisfaction; in line with some previous studies (e.g., Kim et al., 2004).

Therefore, mobile service providers in Zambia should strive for a high quality of service provision if they are to achieve customer satisfaction and consequently customer loyalty. The finding that corporate image is positively associated with customer satisfaction is not incongruent with a number of previous studies (e.g., Lai et al., 2009), hence its importance in the Zambian context. As expected, an inverse relationship between price and customer satisfaction was found, but it was not statistically significant. This finding is consistent with some previous studies (e.g., Martín-Consuegra et al., 2007) which found that price affected customer satisfaction but contradicts other studies such as Adeleke and Aminu (2012) who price not to be a determinant of customer satisfaction and customer loyalty. Even not statistically significant, the finding on price has operational and strategic importance as pricing still needs to be taken into consideration, together with the other factors, as a possible driver of customer satisfaction and loyalty in the Zambian mobile telecommunications sector.

The findings of this study provide useful guidelines for mobile services providers regarding the important drivers of customer satisfaction and customer loyalty. These guidelines will become particularly important as mobile penetration approaches $100 \%$ because the only way service providers will be able to grow market share will be by attracting customers from competitors and retaining existing customers. As argued by Kim et al. (2004, p. 146) "the best core marketing strategy for the future is try to retain existing customers by heightening customer loyalty and customer value". Most importantly according to this study, the following should be addressed. Service providers should invest in network 
expansion activities if they are to achieve customer satisfaction and customer loyalty. After network coverage, attention should on customer service improvement. For example, service providers should ensure easy and convenient access to customer care centers with a view to facilitating customer retention

\section{Research limitations and direction for future research}

This study was limited in at least two some ways. First, the data were gathered from one city only. Future studies could consider using data from other provinces in Zambia. Second, future studies could consider extending their reach to other African countries for comparison. Third, since the variances accounted for in customer satisfaction and customer loyalty were only $54 \%$ and $37.4 \%$ respectively, there must be other important influencing factors that should be included in future studies. It is suggested that identifying and explaining these influencing factors is an important direction for future research.

\section{References}

Adeleke, A. and Sirajul, A.A. (2012). The determinants of customer loyalty in Nigeria's GSM market. International Journal of Business and Social Science, 3(14), pp. 209-222.

Ahmad, R. and Butte, F. (2002). Customer retention management: a reflection of theory and practice. Marketing Intelligence and Planning, 20(3), pp. 149-161.

Anderson, E.W., Cornell, C. and Lehmann, D.R. (1994). Customer satisfaction, market share and profitability: Findings from Sweden. Journal of Marketing, pp. 53-66.

Aydin, S. and Ozer, G. (2005). The analysis of antecedents of customer loyalty in the Turkish mobile telecommunication market. European Journal of Marketing, 39(7), pp. 910-925.

Bagozzi, R.P. and Yi, Y. (1988). On the evaluation of structural equation models. Journal of the Academy of Marketing Science, 16(1), pp. 74-94.

Bitner, M.J., Booms, B.H. and Tetreault, M.S. (1990). The service encounter: diagnosing favorable and unfavorable incidents. Journal of Marketing, 54(1), pp. 71-84.

Bloemer, J., Ruyter, K.D. and Peeters, P. (1998). Investigating drivers of bank loyalty: the complex relationship between image, service quality and satisfaction. Journal of Marketing, 16(7), pp. 276-286.

Bolton, R.N. and Drew, J.H. (1991). A multistage model of customers' assessments of service quality and value. Journal of Consumer Research, 17(4), pp. 375-384.

Boohene, R. and Agyapong, G.K.Q. (2011). Analysis of the antecedents of customer loyalty of telecommunication industry in Ghana: the case of Vodafone (Ghana). International Business Research, 4(1), pp. 229-240.

Boora, K.K. and Singh, H. (2011). Customer loyalty and its antecedents: a conceptual framework understanding emarketing-optimization of resources. Asia Pacific Journal of Research in Business Management, 2(1), pp. 151-164.

Brown, T.J., Churchill, G.A. and Peter, J.P. (1993). Improving the measurement of service quality. Journal of Retailing, 69(1), pp. 127-139.

Buzzell, R.D. and Gale, B.T. (1987). The PIMS Principles: Linking Strategy to Performance. New York: The Free Press.

Cohen, J. (1988). Statistical Power Analysis for the Behavioral Sciences, 2nd ed., Lawrence Erlbaum Associates, Hillsdale, NJ.

Coyles, S. and Gokey, T. (2005). Customer retention is not enough. Journal of Consumer Marketing, 22(2), pp. 101-105.

Deng, Z., Lu, Y., Wei, K.K. and Zhang, J. (2010). Understanding customer satisfaction and loyalty: an empirical study of mobile instant messages in China. International Journal of Information Management, 30(4), pp. 289-300.

Dick, A. and Basu, K. (1994). Customer loyalty: toward an integrated conceptual framework. Journal of Marketing Science, 22(2), pp. 99-113.

Eggert, A. and Ulaga, W. (2002). Customer perceived value: a substitute for satisfaction in business markets? Journal of Business \& Industrial Marketing, 17(2/3), 107-118.

Fornell, C. (1992). A national customer satisfaction barometer: the Swedish experience. Journal of Marketing, pp. 6-21.

Fornell, C. and Larcker, D.F. (1981). Structural equation models with unobservable variables and measurement error: Algebra and statistics. Journal of marketing research, pp.382-388.

Ganguli, S. and Roy, S.K. (2011). Generic technology-based service quality dimensions in banking: Impact on customer satisfaction and loyalty. International Journal of Bank Marketing, 29(2), pp. 168-189.

Gerpott, T.J., Rams, W. and Schindler, A. (2001). Customer retention, loyalty, and satisfaction in the German mobile cellular telecommunications market. Telecommunications Policy, 25(4), pp. 249-269.

Gotlieb, J.B., Grewal, D. and Brown, S.W. (1994). Consumer satisfaction and perceived quality: complementary or divergent constructs? Journal of Applied Psychology, 79(6), pp. 875-885.

Hair, J.F., Ringle, C.M. and Sarstedt, M. (2011). PLS-SEM: Indeed, a silver bullet. Journal Marketing Theory and Practice, 19(2), pp. 139-151. 
Haquea, A., Rahmanb, S. and Rahmanc, M. (2010). Factors determinants the choice of mobile service providers: structural equation modeling approach on Bangladeshi consumers. Business and Economics Research Journal, 1(3), pp. 7-34.

Heskett, J.L. and Sasser Jr, W.E. (2010). The Service Profit Chain. In Handbook of Service Science. Springer US, pp. 1929.

Ibok, N.I. (2008). The concept of satisfaction and its relevance to consumer behavior: implications for theory development. The Nigerian Accounting Horizon, 1(1), pp. 208-215.

Kim, M.K., Wong, S.F., Chang, Y. and Park, J.H. (2016). Determinants of customer loyalty in the Korean smartphone market: moderating effects of usage characteristics. Telematics and Informatics, 33(4), pp. 936-949.

Kim, M.K., Park, M.C. and Jeong, D.H. (2004). The effects of customer satisfaction and switching barrier on customer loyalty in Korean mobile telecommunication services. Telecommunications Policy, 28(2), pp. 145-159.

Kim, Y. and Lee, J. (2011). Relationship between corporate image and customer loyalty in mobile communications service markets. African Journal of Business Management, 4(18), pp. 4035-4041.

Krishnamurthi, L. and Raj, S.P. (1991). An empirical analysis of the relationship between brand loyalty and consumer price elasticity. Marketing Science, 10(2), pp. 172-183.

Kumar, V., Batista, L. and Maull, R. (2011). The impact of operations performance on customer loyalty. Service Science, 3(2), pp. 158-171.

Lai, F., Griffin, M. and Babin, B.J. (2009). How quality, value, image, and satisfaction create loyalty at a Chinese telecom. Journal of Business Research, 62(10), pp. 980-986.

Lee, M. and Cunningham, L.F. (2001). A cost/benefit approach to understanding service loyalty. Journal of Service Marketing, 15(2), pp. 113-130.

Lim, H., Widdows, R. and Park, J. (2006). M-loyalty: winning strategies for mobile carriers. Journal of Consumer Marketing, 23(4), pp. 208-210.

Liu, L. (2008). Study of the relationship between customer satisfaction and loyalty in telecom enterprise. 4th International Conference on Wireless Communications, Networking and Mobile Computing, 1-7.

Liu, C.-T., Guo, Y.M. and Lee, C.-H. (2011).The effects of relationship quality and switching barriers on customer loyalty. International Journal of Information Management, 31(1), 71 - 79.

Lucas, R.W. (2005). Customer Service: Building Successful Skills for the Twenty-First Century, 3rd ed. McGraw-Hill Irwin, Boston.

Martín-Consuegra, D., Molina, A. and Esteban, Á. (2007). An integrated model of price, satisfaction and loyalty: an empirical analysis in the service sector. Journal of Product E Brand Management, 16(7), pp. 459-468.

McDougall, G.H. and Levesque, T. (2000). Customer satisfaction with service: putting perceived value into the equation. Journal of Services Marketing, 14(5), pp. 392-410.

Negi, R. (2009). Determining customer satisfaction through perceived service quality: A study of Ethiopian mobile users. International Journal of Mobile Marketing, 4(1), pp. 31-38.

Oliver, R.L. (1999). Whence customer loyalty? Journal of Marketing, 63(4), pp. 33-44.

Oliver, R.L. (1992). An investigation of the attribute basis of emotion and related effects in consumption: suggestions for a stage specific satisfaction framework, in: J. Sherry, B. Sternthal (Eds.), Advance in Consumer Research (vol. 19), Association for Consumer Research, Provo, UT, pp. 237-244.

Pew Research Center, April 2015, “Cell Phones in Africa: Communication Lifeline"

Prentice, C. (2014). Who stays, who walks, and why in high-intensity service contexts. Journal of Business Research, 67(4), pp. 608-614.

Rajaobelina, L. and Bergeron, J. (2009). Antecedents and consequences of buyer-seller relationship quality in the financial services industry. International Journal of Bank Marketing, 27(5), pp. 359-380.

Ringle, C., Wende, S. and Will, A. (2005). SmartPLS 2.0 (Beta). Hamburg, (www.smartpls.de).

The Post (2015), Retrieved from https:/ / www.facebook.com/postzambia/posts/1775764015982772 (25/12/16)

Venetis K.A. and Ghauri P. (2004). Service quality and customer retention: building long term relationships. European Journal of Marketing, 38(11/12), pp. 77-98.

Woo, K. and Fock, H. (1999). Customer satisfaction in the Hong Kong mobile phone industry. Service Industry Journal, 19(3), pp. 162-174.

Zambia Information and Communications Authority (ZICTA). (2013). Annual Report 2013. 